\author{
A.A. Seitmagzimov, G.M. Seitmagzimova, Zh.K. Dzhanmuldaeva \\ M. Auezov South Kazakhstan State University, Shymkent, Kazakhstan \\ (E-mail: galinaseit@mail.ru)
}

\title{
Hydrothermal grown iron oxide films on the surface of titanium and conductive glasses and their current characteristics in water photolysis
}

\begin{abstract}
The relevance of photolysis on semiconductor electrodes since the pioneer work of Fujishima and Honda on metallic titanium does not lose sharpness due to new possibilities for developing new materials, such as conductive glasses, for which photolysis cells with semi-transparent semiconductor layer can be created. We have compared properties of such glasses with a metal for hydrothermal conditions of iron oxide synthesis. Iron oxide films have also been obtained by introducing a number of cations to modify semiconductor systems $\left(\mathrm{Fe}_{2} \mathrm{O}_{3}\right)$. It turned out that the nature of the substrate significantly affects the properties of the formed conductive film, which ultimately forms the level of anodic photocurrents in the layer of iron oxide semiconductor. We have investigated current characteristics of such films; it was shown that charging processes occur better on metallic titanium than on conductive glasses. We consider that the metal substrate significantly reduces regeneration processes both in the semiconductor layer and at the interface. Thus, formed $\mathrm{Ti} / \mathrm{Fe}_{2} \mathrm{O}_{3}$ electrolyte heterojunction is more efficient than the conducting glass $/ \mathrm{Fe}_{2} \mathrm{O}_{3}$ electrolyte system. However, this does not mean that glass is less promising for photolysis systems. It is necessary to achieve more acceptable conditions for the synthesis of semiconductor material.
\end{abstract}

Keywords: iron oxide, conductivity, spectrum, current-voltage characteristic, anode photocurrent, band gap, semiconductor, doping.

\section{Introduction}

Semiconductor transition metal oxides are known for their properties as anode materials for the model processes of water photoelectrolysis [1]. Among this variety of anode materials $\left(\mathrm{TiO}_{2}, \mathrm{ZnO}, \mathrm{Fe}_{2} \mathrm{O}_{3}, \mathrm{WO}_{3}\right.$, etc.), iron oxide has always attracted itself as an optimal material from point of view of its optical characteristics the band gap width equals $2.1 \mathrm{eV}$, herewith the photo corrosion for this material is minimal. On the other hand, this material has intrinsic essential disadvantages, namely increased recombination $[2,3]$ and it's very limited thickness of an active layer, just a few nanometers [4]. From this point of view, the production of $\mathrm{Fe}_{2} \mathrm{O}_{3}$ films in hydrothermal conditions is always attractive, because this method is an universal one and it allows to vary the properties of films in very wide range, both in thickness and in composition.

It was shown earlier that under the studied conditions of hydrothermal synthesis [5] at certain concentration ranges of iron chloride (III) it is possible to dope titanium dioxide films with iron ions. It gives a significant improvement of current characteristics of photoelectrodes. It was of interest to study the formation of iron oxide films under the same conditions on pure films of metallic titanium and on a conducting glass. For that we raised concentration of the electrolyte $\mathrm{FeCl}_{3} 5 \mathrm{H}_{2} \mathrm{O}$ solution, which allowed to grow films of pure iron oxide on the surface of titanium and conductive glass in hydrothermal conditions.

\section{Experimental}

The investigations were conducted on metallic titanium plates of size $1.5 \times 1.5 \mathrm{~cm}$ (VT6 titanium grade) of composition Ti-6.25 Al-4.1 with small admixture of aluminum and vanadium (Government Standard 19807-91) with a current collector of the same titanium, as well as on conductive glass Fluorine Tin Oxide (FTO) with conductivity less than $15 \mathrm{ohms} / \mathrm{cm}^{2}$ of firm «LATECH».

Previously we applied 2.0-2.5 g/l FeCl $35 \mathrm{H}_{2} \mathrm{O}$ solution for modification of titanium dioxide films on the metallic titanium with hydrochloric acid solution acidifying. We raised the concentration of iron chloride to 5-10 g/l, which allowed us to form under the same conditions $\left(190{ }^{\circ} \mathrm{C}, 5\right.$ hours $)$ iron oxide films in an autoclave.

Hydrothermal synthesis of films was carried out in a laboratory autoclave under pressure of 0.5 MPa with plates position shown in Figure 1. After the hydrothermal synthesis, the films were washed with distilled water, dried and then annealed in air at $500{ }^{\circ} \mathrm{C}$ for 1 hour. In parallel, plates of conductive glasses were processed in the same fluoroplastic glass. Then the plates after washing with water were also annealed at $500{ }^{\circ} \mathrm{C}$ for an hour. 


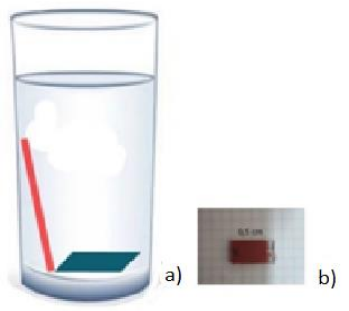

$a$ - titanium plate (vertical position) and glass plate (horizontal position); $b$ - the size of the glass electrode with iron oxide layer

Figure 1. Scheme of samples arrangement in the autoclave

$\mathrm{X}$-ray analysis of films was performed at the stationary installation of DRONE-3 with $\mathrm{Cu}-\mathrm{K} \alpha$ radiation directly from the metallic plates of anodized titanium.

The anodic photocurrent of titanium-oxide electrodes was conducted by a three-electrode scheme; a platinum wire served as the counter electrode, the comparison electrode was silver- chloride one. For iron oxide film illumination a xenon lamp without light filters was used. Illumination of the samples was measured with a light meter and accounted for xenon lamp as (160-180) $10^{3}$ Lux and for UV lamp - as $12 \cdot 0^{3}$ Lux. The level of illumination on the sun in the latitude of Shymkent (South Kazakhstan) in June, measured at midday, was $130 \cdot 10^{3}$ Lux. Current-voltage characteristic was double-checked for different synthesis conditions, the accuracy was confirmed by 3-4 parallel sample measurements, and the photocurrent dependence was constructed from their averaged values. Relative standard deviation from the average value is $0.5 \%$.

Micrographs and semi-quantitative analysis of the electrode surface were performed using scanning electron microscope JSM-6490LV (JEOL, Japan). Optical spectra of glasses were recorded on a Cary-50 spectrophotometer in a transmission mode.

\section{Results and Discussion}

Simultaneous hydrothermal treatment of titanium and glasses in the autoclave allowed to form a layer of iron oxide film on the surface of the plates when changing iron trichloride solution concentration. This can be clearly seen from the cross-section of the glass plate (Fig. 2).

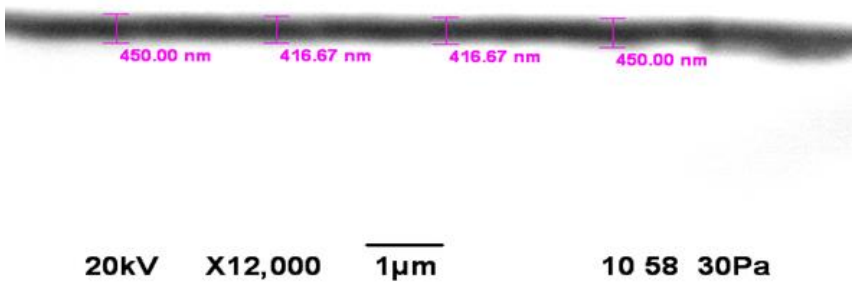

Figure 2. Micrograph of iron oxide film of on the glass plate (inverted image)

It is possible to determine the thickness of iron oxide layer in the limit of $416-450 \mathrm{~nm}$, with the transmission spectrum (Fig. 3) identified as a layer of iron oxide. For example, it is in good agreement with the spectra of iron oxide in [5] in the limit of 350-800 $\mathrm{nm}$. We can see the absorption limit which is in line with approximately $400 \mathrm{~nm}$.

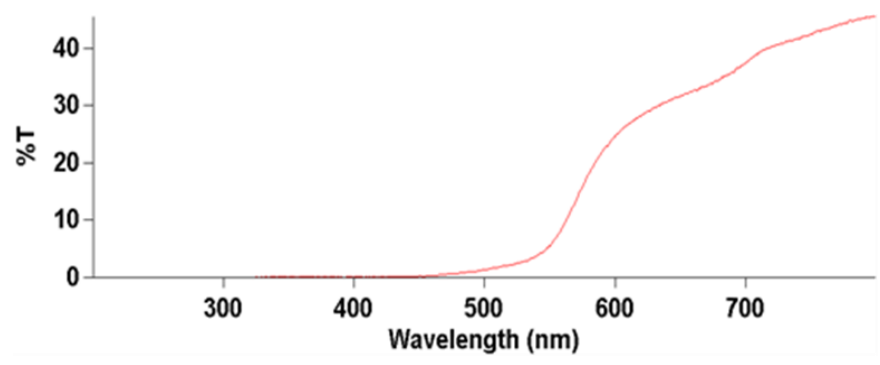

Figure 3. Transmission spectra of glass after glass treatment with iron trichloride in an autoclave 
The presence of iron oxide film on titanium is also recorded on metal plate X-ray diffraction pattern (Fig. 4). However, due to the hematite signal weakness, the main peak of metallic titanium outweighs the iron peak.

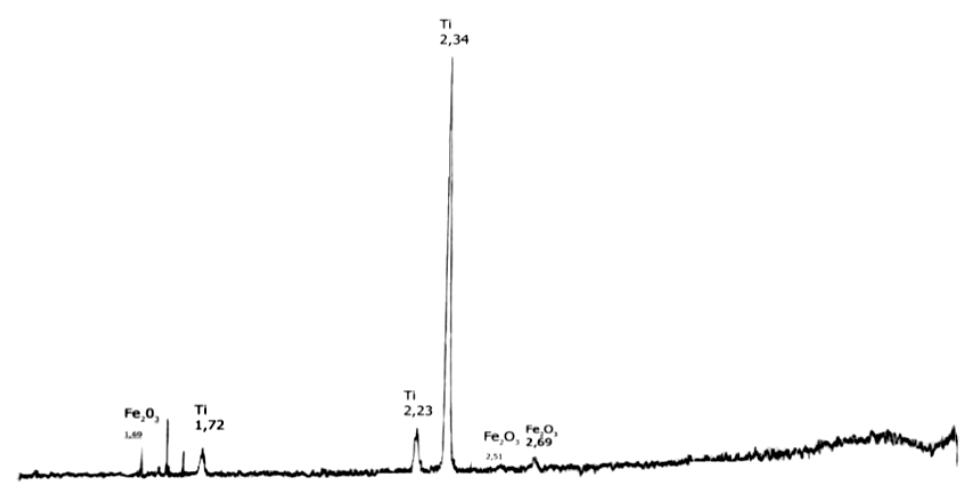

Figure 4. X-ray diffraction pattern of titanium plate with iron oxide layer

Figure 5 shows the current-voltage characteristic of the dark current for the electrode on titanium. It can be seen that there is no dark current within the potentials up to $800 \mathrm{mV}$.

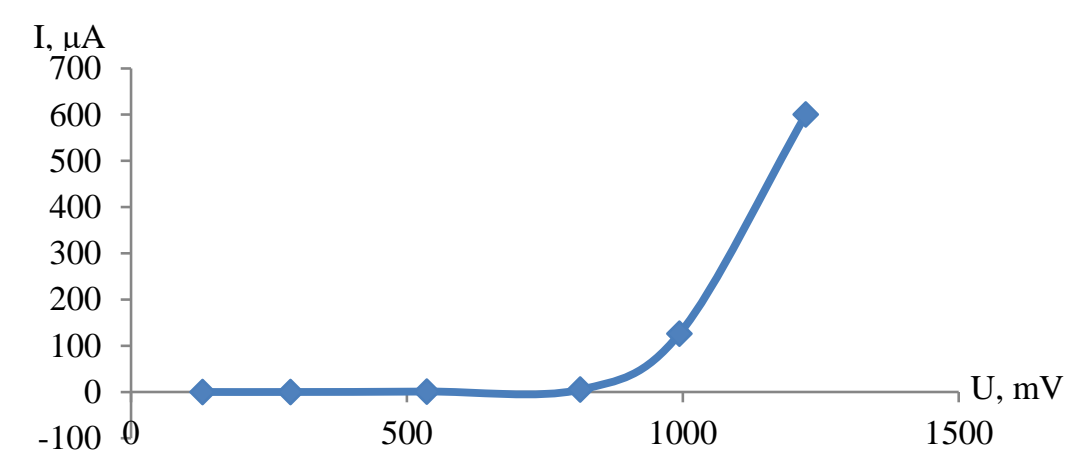

Figure 5. Current-voltage characteristic of a titanium electrode without lighting

An interesting current characteristic for titanium after titanium annealing in the air at $500{ }^{\circ} \mathrm{C}$ is given in Figure 6 (blue line). Annealing of titanium in the air leads to the formation of titanium dioxide film, and its current characteristics are insignificant - 15-20 $\mu$ a (blue line), but increased current characteristics for iron oxide after hydrothermal synthesis and subsequent annealing of such a sample at $500{ }^{\circ} \mathrm{C}$ for 1 hour (red line) are obvious.

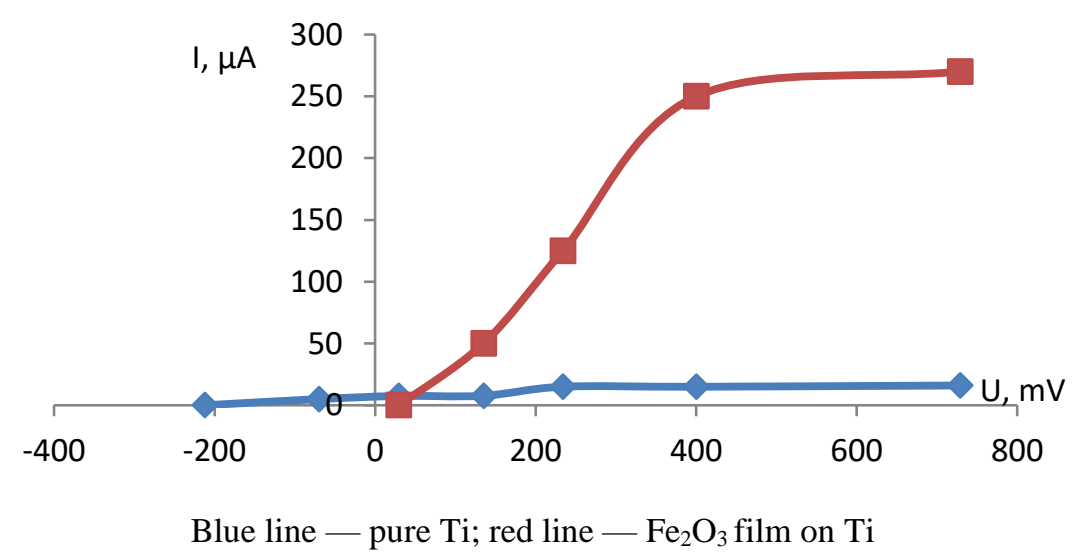

Figure 6. Current-voltage characteristic of pure titanium after annealing titanium dioxide film (blue line) and iron oxide film on titanium after annealing at $500^{\circ} \mathrm{C}$ (red line) 
Current characteristics for hematite on glass are almost identical (Fig. 7). Since the synthesis conditions for pairs of $\mathrm{Ti} / \mathrm{Fe}_{2} \mathrm{O}_{3}$ and glass $/ \mathrm{Fe}_{2} \mathrm{O}_{3}$ were identical (Fig. 1), we associate such a difference of current characteristics with the formation of the hematite boundary with the substrate, where in the case of glass the current characteristics are minimal, and when the titanium - hematite boundary is formed, the current characteristics are much higher. Perhaps it is precisely the recombination processes at the substrate, because hematite interface is significantly reduced in the case of $\mathrm{Ti} / \mathrm{Fe}_{2} \mathrm{O}_{3}$ pair as compared with the glass $/ \mathrm{Fe}_{2} \mathrm{O}_{3}$ pair.

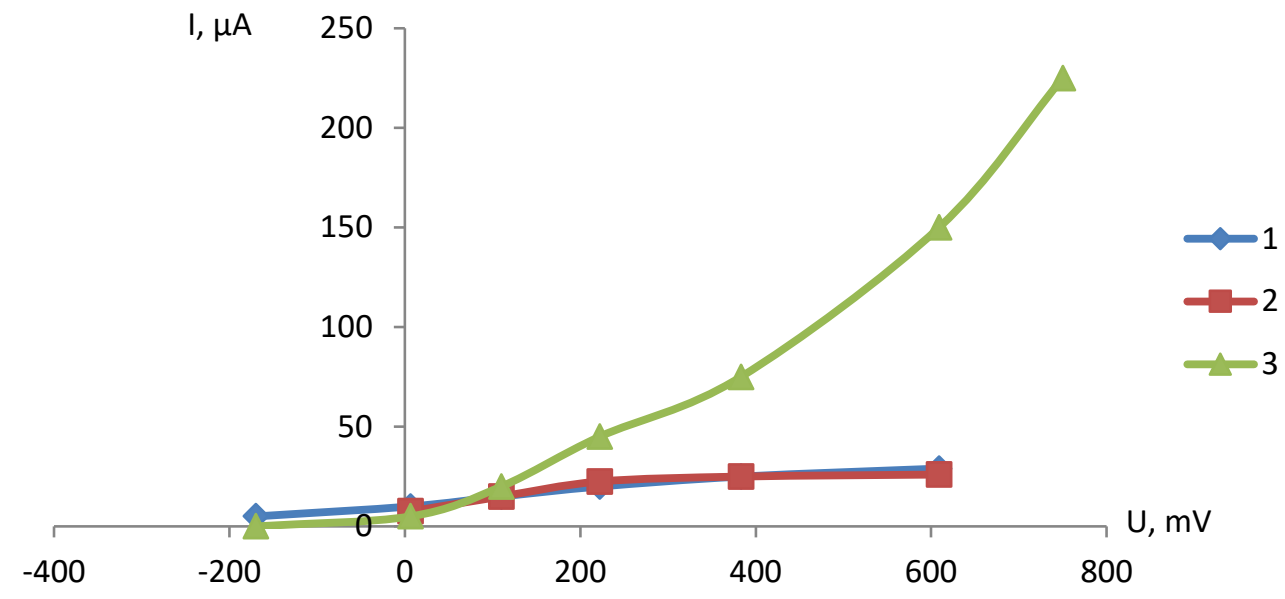

1 - glass electrode, $\mathrm{T}=500{ }^{\circ} \mathrm{C}, \tau=1 \mathrm{~h} ; 2-$ glass electrode, $\mathrm{T}=500{ }^{\circ} \mathrm{C}, \tau=1 \mathrm{~h} ; 3-\mathrm{Ti}$ electrode

Figure 7. Anodic photo current of iron oxide films on glass and titanium

Figure 7 clearly shows the growth of current characteristics up to $250 \mu \mathrm{A}$. Photo current on glass electrodes is insignificant and does not exceed $30 \mu \mathrm{A}$ (blue line - photo current during annealing at $500{ }^{\circ} \mathrm{C}$ for 1 hour and red line - photo current during annealing glass at $700{ }^{\circ} \mathrm{C}$ for 10 minutes). It can be seen at Figure 7 that the glass annealing does not lead to significant change of current characteristics of hematite on the glass. At the same time, a sharp (more than 5 times) increase of photo current on titanium electrodes is observed (green line). We assume that such a significant increase of photo current is associated with the formation of the $\mathrm{Ti} / \mathrm{Fe}_{2} \mathrm{O}_{3}$ heterojunction. We suppose that the conductivity incompleteness at the boundary is significantly reduced compared to the same transition at the glass $/ \mathrm{Fe}_{2} \mathrm{O}_{3}$ boundary, so the conductivity of the «titanium» electrode is significantly higher than that of the «glass» electrode.

We have attempted to introduce other ions (for example, $\mathrm{Ni}, \mathrm{Co}, \mathrm{Ag}, \mathrm{Cu}$ as well as a number of other cations) into the process of synthesis of iron oxide films and thereby to change film conductivity. To do this, 20 to $100 \mathrm{~g} / \mathrm{l}$ of the corresponding cation was introduced into the initial electrolyte containing $2-2.5 \mathrm{~g} / \mathrm{l}$ $\mathrm{FeCl}_{3} \cdot 5 \mathrm{H}_{2} \mathrm{O}$. The Figure 8 shows the spectrogram of the film, to which we tried to introduce a solution $\mathrm{Ni}\left(\mathrm{NO}_{3}\right)_{2} \cdot 6 \mathrm{H}_{2} \mathrm{O}$. Then this solution was also autoclaved like for the initial iron oxide electrolyte and the preparation was carried out similarly.
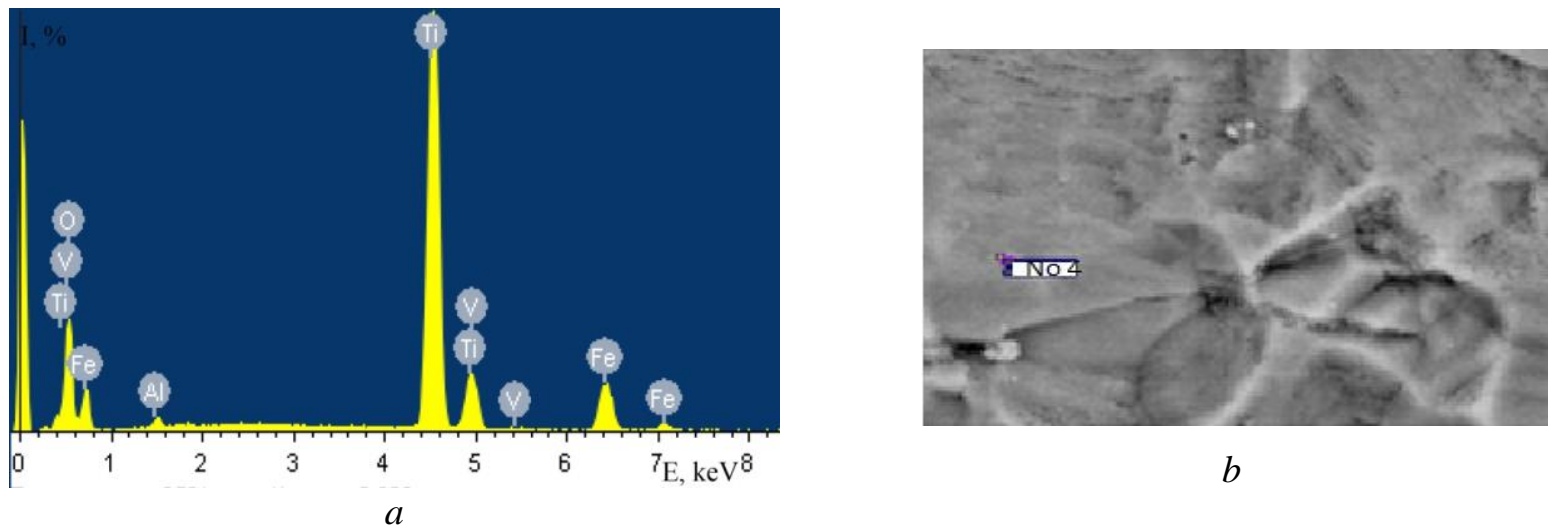

Figure 8. Spectrogram $(a)$ and micrograph $(b)$ of the iron oxide film with another cation introduction 
We couldn't find any traces of the cation injected in the titanium film; only Fe and Ti elements and traces of $\mathrm{Al}$ and $\mathrm{V}$ elements are found on the spectrogram (Figure 8). Thus, hydrothermal conditions do not allow to introduce the accompanying cations into the synthesized film and the iron oxide film is formed on the surface in pure form. Thus, we did not find any improvement or degradation of the iron oxide layer on the current characteristics of the synthesized films (Fig. 8).

Current-voltage characteristic is peculiar as well in this case (Fig. 9). The current values fluctuate (red line) at approximately the same values as for the original iron oxide (blue line). Such insignificant fluctuations fit into the general paradigm of current-voltage characteristic dependence. Thus, we did not detect the improvement or degradation of the iron oxide layer in synthesized films with a cation.

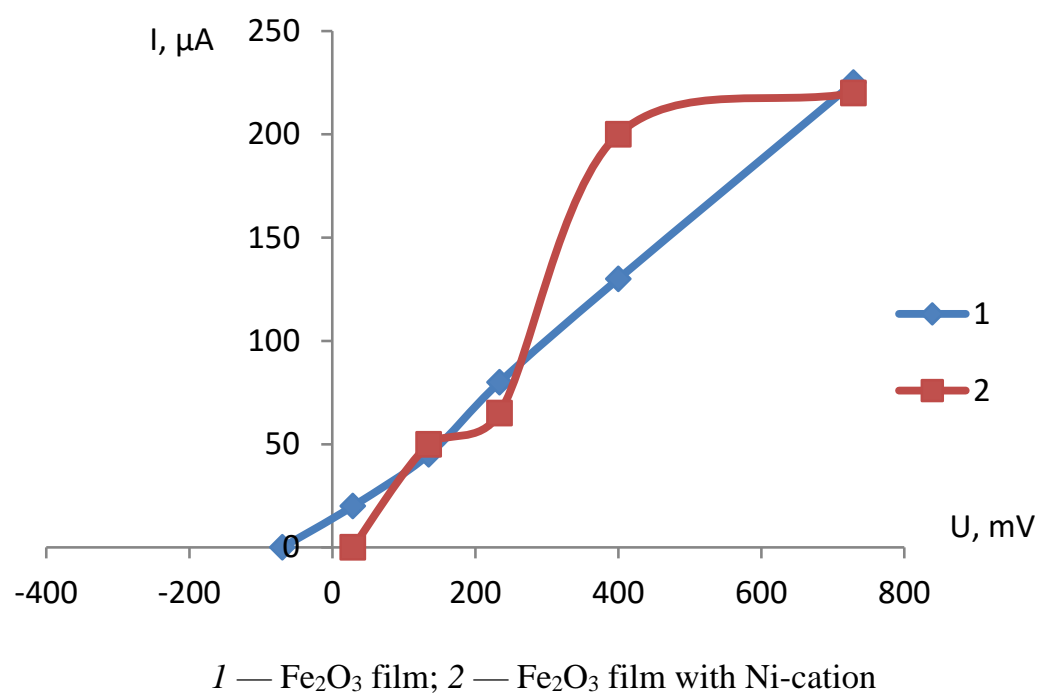

Figure 9.Current-voltage characteristicsof iron oxide films (blue line) and films obtained in the presence of much nickel cations in a solution (red line)

We suppose that under hydrothermal conditions, an iron oxide film was formed on titanium, the electrophysical properties of which are very dependent on the properties of the substrate, i.e. titanium (Fig. 10).

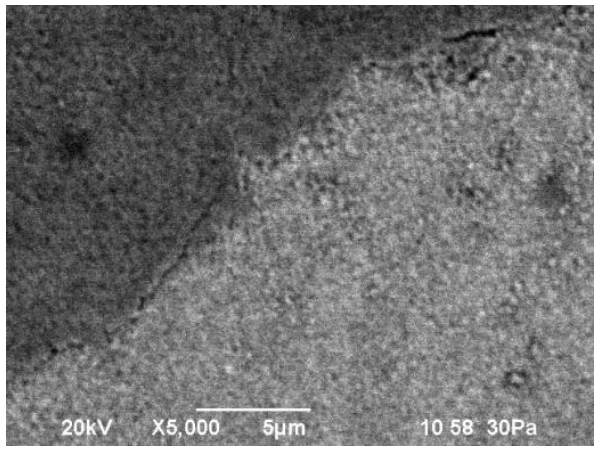

$a$

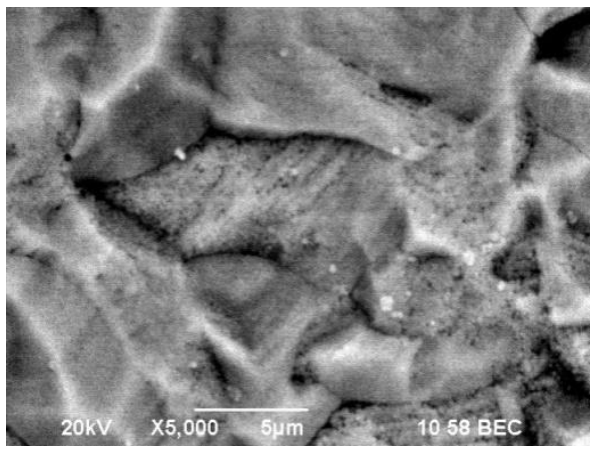

$b$

Figure 10. Micrographs of iron films on glass $(a)$ and titanium $(b)$

In this case, we assume that the $\mathrm{Ti} / \mathrm{Fe}_{2} \mathrm{O}_{3}$ heterojunction, as well as the $\mathrm{Ti} / \mathrm{Fe}_{2} \mathrm{O}_{3}-\mathrm{NaOH}$ electrolyte system itself, is a system that significantly reduces regeneration processes in the semiconductor layer and this sharply raises current characteristics of photoelectrodes. From these positions, perhaps, similar processes are described by authors of the publication [7], who obtained current characteristics three times the best of ours, i.e. $1.1 \mathrm{~mA} / \mathrm{cm}^{2}$.

\section{Conclusion}

Iron oxide films were formed and obtained under hydrothermal conditions on metallic titanium and conductive glasses. It was shown that the current characteristics of the metallic substrate are more than an order 
of magnitude better than for glass. It is obvious that under identical synthesis conditions (hydrothermal growth, conducting basis) the formation of heterojunction largely depends on the substrate nature. A significant difference in current characteristics for different substrates is associated with the formation of a semiconductor layer, where the regeneration processes are very reduced for metallic titanium than for conductive glass.

\title{
References
}

1 Плесков Ю.В. Фотоэлектрохимическое преобразование солнечной энергии / Ю.В. Плесков. — М.: Химия, 1990. $176 \mathrm{c}$.

2 Dare-Edwards M.P. Electrochemistry and Photoelectrochemistry of Iron (III) oxide / M.P. Dare-Edwards, J.B. Goodenough, A. Hamnett, P.R. Trevellick // Journal of the Chemical Society, Faraday Trans. — 1983. — Vol. 1, No. 79. — P. $2027-2041$.

3 Kay A. New Benchmark for Water Photooxidation by Nanostructured A-Fe $\mathrm{O}_{3}$ Films / A. Kay, I. Cesar, M. Grätzel // Journal of the American Chemical Society. — 2006. - No. 128. - P. 15714-15721.

4 Kennedy J.H. Photoactivity of Polycrystalline Alpha- $\mathrm{Fe}_{2} \mathrm{O}_{3}$ Electrodes Doped with Group IVa Elements / J.H. Kennedy, M. Anderman, R. Shinar // Journal of the Electrochemical Society. — 1981. — No. 11. — P. 2371-2373.

5 Seitmagzimov A.A. Modification of Titanium Oxide Films by Ferric Ions in Hydrothermal Conditions and their Photo-Electrochemical Properties / A.A. Seitmagzimov, G.M. Seitmagzimova // Asian Journal of Chemistry. — 2015. — Vol. 27, No. 4. — P. 1521-1524.

$6 \mathrm{Xu}$ Zong. A scalable colloidal approach to prepare hematite films for efficient solar water splitting / Zong Xu, Thaweesak Supphasin, Xu Hongyi, Xing Zheng, Zou Jin, Lua Gaoqing (Max), Wang Lianzhou // Physical Chemistry Chemical Physics. — 2013. - Vol. 15, No. 29. - P. 12314-12321. DOI: 10.1039/c3cp52153b.

7 Jin Hyun Kim. Hetero-type dual photoanodes for unbiased solar water splitting with extended light harvesting / Jin Hyun Kim, Ji-Wook Jang, Yim Hyun Jo, Fatwa F., Young Hye Lee, Roel van de Krol, Jae Sung Lee // Nature Communications. — 2016. — No. 7. — P. 13380. DOI: $10.1038 /$ ncomms 13380 .

\section{А.А. Сейтмагзимов, Г.М. Сейтмагзимова, Ж.К. Джанмулдаева \\ Титан және өткізуші шынылар бетіндегі гидротермалды өсірілген темір оксидінің қабықшалары және олардың су фотолизіндегі токтық сипаттамалары}

\begin{abstract}
Фуджишима мен Хонданың алғашқы жұмыстарынан бастап жартылай өткізгіш электродтардағы фотолиздің өзектілігі жаңа материалдарды игерудің мүмкіндіктеріне байланысты өткірлігін жоғалтпайды, атап айтқанда өткізгіш шынылар олар үшін жартылай өткізгіштің жартылай мөлдір қабаты бар фотолизді ұяшықтар жасалуы мүмкін. Темір оксиді синтезінің гидротермалдық жағдайлары үшін осы шынылардың металмен салыстырғандағы қасиеттері салыстырылған. Сондай-ақ жартылай өткізгіш жүйелерді модификациялау үшін $\left(\mathrm{Fe}_{2} \mathrm{O}_{3}\right)$ бірнеше катиондар енгізіп, темір оксидінің қабықшалары алынды. Төсеніштің табиғаты қалыптасатын өткізгіш қабықшаның қасиеттеріне елеулі әсер ететіні анықталды, бұл соңында теміроксидті жартылай өткізгіштің қабатында анодты фототоктар деңгейін қалыптастырды. Авторлар қабықшалардың ток сипаттамаларын зерттеген, олардың нәтижелері металл титанда өткізуші шынылармен салыстырғанда зарядтау процестері жақсы жүретінін көрсетті. Біз металл төсеніш жартылай өткізгіштің қабатындағы және фазалар шекарасында регенерациялық процестерді айтарлықтай төмендетеді деп есептейміз. Осылайша, қалыптасатын $\mathrm{Ti} / \mathrm{Fe}_{2} \mathrm{O}_{3}$ әртекті өткізу «өткізуші шыны/ $\mathrm{Fe}_{2} \mathrm{O}_{3}$-электролит» жүйесіне қарағанда тиімдірек. Дегенмен, шынылардың фотолиздік жүйелер үшін болашағы жоқ деп айтуға болмайды. Жартылай өткізгіш материалдарды синтездеудің қолайлы жағдайларына қол жеткізу қажет.
\end{abstract}

Кілт сөздер: темір оксиді, өткізгіштік, спектр, вольтамперлік сипаттама, анодты фототок, тыйым салынған аймақтың ені, жартылай өткізгіш, допирлеу.

\section{А.А. Сейтмагзимов, Г.М. Сейтмагзимова, Ж.К. Джанмулдаева \\ Гидротермально выращенные пленки оксида железа на поверхности титана и проводящих стекол и их токовые характеристики при фотолизе воды}

Актуальность фотолиза на полупроводниковых электродах со времен пионерской работы Фуджишимы и Хонды на металлическом титане не теряет остроты ввиду новых возможностей освоения новых материалов, таких как проводящие стекла, для которых могут быть созданы фотолизные ячейки с 
полупрозрачным слоем полупроводника. Нами сопоставлены свойства таких стекол по сравнению с металлом для гидротермальных условий синтеза оксида железа. Также получены пленки оксида железа при введении ряда катионов для модификации полупроводниковых систем ( $\left.\mathrm{Fe}_{2} \mathrm{O}_{3}\right)$. Как оказалось, природа подложки существенным образом влияет на свойства формируемой проводящей пленки, что, в конечном итоге, формирует уровень анодных фототоков в слое железооксидного полупроводника. Авторами исследованы токовые характеристики таких пленок и показано, что на металлическом титане лучше происходят зарядные процессы, чем на проводящих стеклах. Мы считаем, что металлическая подложка существенно снижает регенерационные процессы как в слое полупроводника, так и на границе фаз. Таким образом, формируемый гетеропереход Ti/ $\mathrm{Fe}_{2} \mathrm{O}_{3}$-электролит более эффективен, чем система «проводящее стекло/ $\mathrm{Fe}_{2} \mathrm{O}_{3}$-электролит». Однако это не свидетельствует о том, что стекла менее перспективны для фотолизных систем. Необходимо добиваться более приемлемых условий синтеза полупроводникового материала.

Ключевые слова: оксид железа, проводимость, спектр, вольтамперная характеристика, анодный фототок, ширина запрещенной зоны, полупроводник, допирование.

\section{References}

1 Pleskov, Yu.V. (1990). Fotoelektrokhimicheskoe preobrazovanie solnechnoi enerhii [Photoelectrochemical conversion of solar power]. Moscow: Khimiia [in Russian].

2 Dare-Edwards, M.P., Goodenough, J.B., Hamnett, A., \& Trevellick, P.R. (1983). Electrochemistry and Photoelectrochemistry of Iron (III) oxide. Journal of the Chemical Society, Faraday Trans, 1, 79, 2027-2041.

3 Kay, A., Cesar, I., \& Grätzel, M. (2006). New Benchmark for Water Photooxidation by Nanostructured A-Fe $\mathrm{O}_{3}$ Films. Journal of the American Chemical Society, 128, 15714-15721.

4 Kennedy, J.H., Anderman, M., \& Shinar, R. (1981). Photoactivity of Polycrystalline Alpha-Fe $\mathrm{O}_{3}$ Electrodes Doped with Group IVa Elements. Journal of the Electrochemical Society, 11, 2371-2373.

5 Seitmagzimov, A.A., \& Seitmagzimova, G.M. (2015). Modification of Titanium Oxide Films by Ferric Ions in Hydrothermal Conditions and their Photo-Electrochemical Properties. Asian Journal of Chemistry, 27, 4, 1521-1524.

6 Xu Zong, Supphasin Thaweesak, Hongyi Xu, Zheng Xing, Jin Zou, \& Gaoqing (Max), et.al. (2013). A scalable colloidal approach to prepare hematite films for efficient solar water splitting. Physical Chemistry Chemical Physics, 15, $29,12314-12321$. DOI: $10.1039 / \mathrm{c} 3 \mathrm{cp} 52153 \mathrm{~b}$.

7 Jin Hyun Kim, Ji-Wook Jang, Yim Hyun Jo, Fatwa F., Young Hye Lee, \& Roel van de Krol, et.al. (2016). Hetero-type dual photoanodes for unbiased solar water splitting with extended light harvesting. Nature Communications, 7. DOI: 10.1038/ncomms 13380 . 